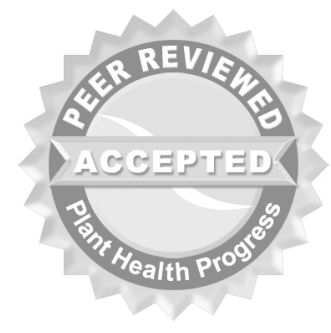

(c) 2006 Plant Management Network.

Accepted for publication 28 July 2006. Published 18 October 2006.

\title{
Host Range of Itersonilia perplexans and Management of Itersonilia Petal Blight of China Aster
}

\author{
R. J . McGovern, Plant Pathology Department, University of Florida- \\ IFAS, Gainesville 32611; H. Horita, Hokkaido Ornamental Plants and \\ Vegetables Research Center, Hokkaido, Japan; C. M. Stiles, Plant \\ Pathology Department, University of Florida-IFAS, Gainesville 32611; \\ and T. E. Seijo, Gulf Coast Research and Education Center, University \\ of Florida-IFAS, Wimauma 33598
}

Corresponding author: R. J. McGovern. rjm@ifas.ufl.edu

McGovern, R. J., Horita, H., Stiles, C. M. and Seijo, T. E. 2006. Host range of Itersonilia perplexans and management of Itersonilia petal blight of China aster. Online. Plant Health Progress doi: 10.1094/PHP-2006-1018-02-RS.

\begin{abstract}
Isolates of Itersonilia perplexans were tested for pathogenicity on 14 different plant species. Isolates from China aster and sunflower were each pathogenic to the other host and both isolates were pathogenic to chrysanthemum and gerbera, causing moderate to high incidences of flower or seedling blight in these hosts. China aster and sunflower isolates were not pathogenic to burdock, but an isolate from burdock was pathogenic to florists' chrysanthemum and gerbera. In a survey of weed species near a cut-flower production facility in southwest Florida, I. perplexans was found in only one weed species, Emilia fosbergii. However, two isolates from this weed host produced severe petal blight symptoms when inoculated onto China aster. Myclobutanil, potassium bicarbonate, and propiconazole were highly effective in reducing disease severity of petal blight in China aster, while azoxystrobin reduced disease moderately in fungicide evaluation trials.

\section{I ntroduction}

Itersonilia perplexans Derx is a dimorphic basidiomycete that has yeast and hyphal phases, produces ballistospores (Fig. 1) that are forcibly ejected and disseminated by air movement, and may produce chlamydospores $(8,19)$. Morphological (presence or absence of chlamydospores) and host range variation within the fungus led some researchers to establish two additional species, I. pyriformans Nyland and I. pastinacae Channon $(6,19)$. However, genetic and nutritional similarities, and mating compatibility among such isolates argue against taxonomic separation $(3,4,24)$. Growth, sporulation, and infection processes of I. perplexans are favored by abundant rainfall, high relative humidity $(>70 \%)$, and cool temperatures $\left(10\right.$ to $\left.15^{\circ} \mathrm{C}\right)(5,12,14)$.
\end{abstract}

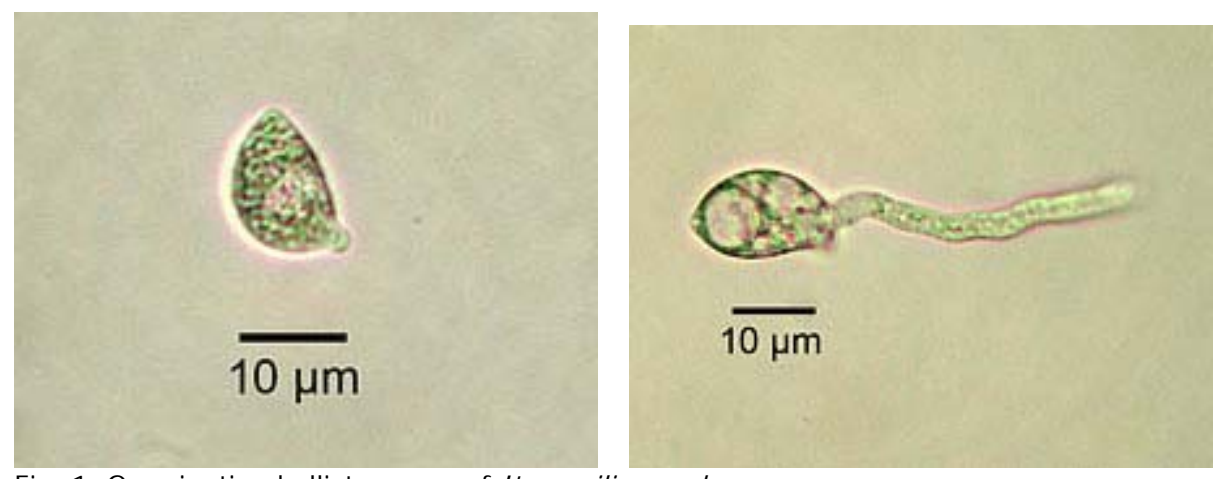

Fig. 1. Germinating ballistospores of I tersonilia perplexans. 
Itersonilia has been detected in Australia, Austria, Canada, Great Britain, Greece, J apan, New Zealand, Netherlands, Portugal, Uruguay, and the United States $(2,3,10,13,21,23,25)$. It causes flower blight in anemone, dahlia, florists' chrysanthemum, and globe artichoke, and various other symptoms including seedling blight, leaf spots/ necrosis, and/ or root cankers in dill, edible burdock, parsnip, and sunflower $(2,4,7,9,11,13,18,20,21,25,26)$. However, isolates exhibit some host specificity with two groups of isolates reported: those causing floral blight in chrysanthemum and other related species and those infecting dill, carrot, parsley, and parsnip $(3,4,6,15)$.

Outbreaks of Itersonilia petal blight occurred at a cut-flower production site in Southwest Florida during 1997 through 1999 resulting in extensive postharvest losses in China aster (Callistephus chinensis (L.) Nees) and sunflower (Helianthus annuus) $(16,22)$ (Figs. 2 and 3). Because petal blight can develop between $1^{\circ}$ and $21^{\circ} \mathrm{C}(14)$, post-harvest damage from I. perplexans may occur in cut-flowers held under refrigeration. In addition, low temperatures did not halt growth or sporulation; infected inflorescences of chrysanthemum were found after 31 days of frosts (11). Interestingly, the disease was previously detected in florists' chrysanthemum at the same production facility in 1973 (17). Itersonilia perplexans has been reported to survive between crops on plant debris, as well as saprophytically on many weeds and cultivated plants especially in the Asteraceae in Great Britain (11) and on many different plant families in the Netherlands (3). Singh and Milne (23) evaluated fungicides for control of chrysanthemum petal blight (involving other pathogens in addition to I. perplexans) in New Zealand. No recent reports have assessed fungicide efficacy in reducing disease caused by I. perplexans.

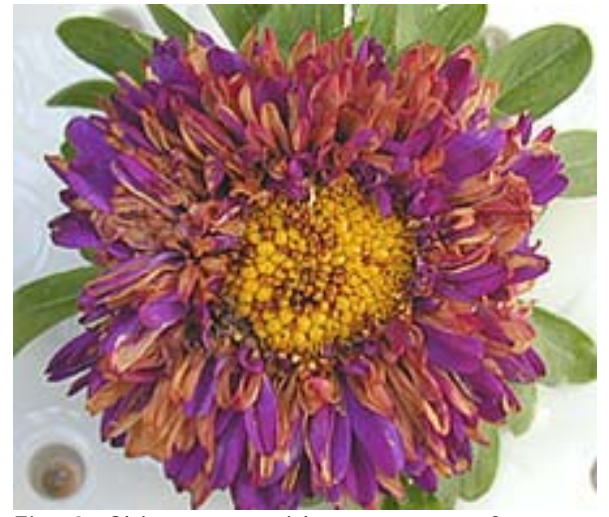

Fig. 2. China aster with symptoms of Itersonilia blight.

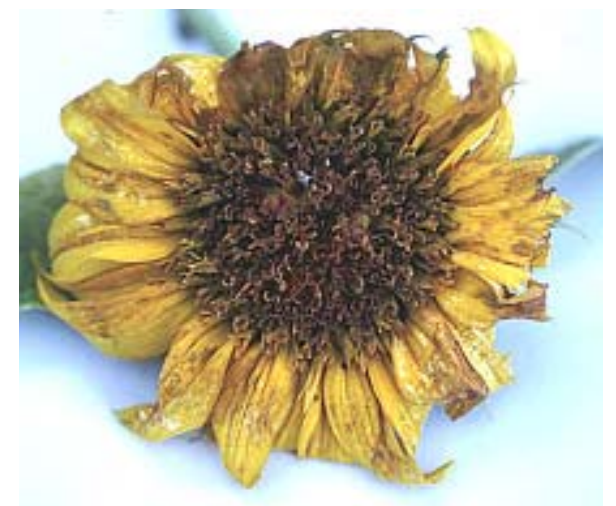

Fig. 3. Sunflower with symptoms of Itersonilia blight.

The objectives of our research were identification of potential inoculum reservoirs through weed surveys and host range studies, comparison of the pathogenicity of I. perplexans from multiple hosts, and evaluation of fungicides including new reduced-risk materials for control of Itersonilia petal blight.

\section{Experimental Host Range of I tersonilia perplexans}

The experimental host range of I. perplexans isolates from China aster (98592), sunflower (99-1051), and edible burdock (IB9602) was tested using 14 different plant species selected primarily from the Apiaceae and Asteraceae families (Table 1). Five to six seedlings or two to six flowers were inoculated by atomizing them with a $1 \mathrm{ml}$ suspension containing $1 \times 10^{4}$ ballistospores $/ \mathrm{ml}$ suspension from 2 - to 4 -week-old fungus cultures grown on $1 / 4$-strength acidified potato dextrose agar ( $1 / 4$ APDA). An equal number of seedlings and flowers sprayed with water served as non-inoculated controls. Inoculated specimens and controls were enclosed in plastic bags and held at $15^{\circ} \mathrm{C}$ for 9 to 11 days. Following incubation, pathogenicity was recorded based on symptom incidence. Incidence on various hosts is summarized in Table 1 in categories of $0 \%, 0$ to $30 \%, 30$ to $60 \%,>60 \%$ disease incidence. Host range tests were completed two times. 
Table 1 . Host range of three Itersonilia perplexans isolates.

\begin{tabular}{|c|c|c|c|c|}
\hline \multirow[b]{2}{*}{ Plant } & \multirow[b]{2}{*}{ Family } & \multicolumn{3}{|c|}{ Pathogenicity rating } \\
\hline & & $\begin{array}{c}\text { 98-592 } \\
\text { (China } \\
\text { aster) }\end{array}$ & $\begin{array}{l}\text { 99-1051 } \\
\text { (Sunflower) }\end{array}$ & $\begin{array}{c}\text { I B9602 } \\
\text { (Edible } \\
\text { burdock) }\end{array}$ \\
\hline Alcea rosea (Hollyhock), $\mathrm{S}^{\mathrm{x}}$ & Malvaceae & $-\mathrm{y}$ & - & - \\
\hline Anethum graveolens (Dill), S & Apiaceae & - & - & - \\
\hline $\begin{array}{l}\text { Arctium lappa (Edible burdock), } \\
\text { S }\end{array}$ & Asteraceae & - & - & +++ \\
\hline $\begin{array}{l}\text { Callistetphus chinensis (China } \\
\text { aster), F }\end{array}$ & Asteraceae & ++ & ++ & - \\
\hline $\begin{array}{l}\text { Chrysanthemum morifolium } \\
\text { (Florists' chrysanthemum), F }\end{array}$ & Asteraceae & +++ & ++ & + \\
\hline Coriandrum sativum (Parsley), S & Apiaceae & - & - & - \\
\hline Coriandrum sativum (Cilantro), S & Apiaceae & - & - & - \\
\hline $\begin{array}{l}\text { Cynara cardunculus (Globe } \\
\text { artichoke), S }\end{array}$ & Asteraceae & - & - & - \\
\hline Daucus carota (Carrot), S & Apiaceae & - & - & - \\
\hline $\begin{array}{l}\text { Daucus carota (Queen Anne's } \\
\text { Lace), S }\end{array}$ & Apiaceae & - & - & - \\
\hline Gerbera jamesonii (Gerbera), F & Asteraceae & +++ & +++ & +++ \\
\hline $\begin{array}{l}\text { Helianthus annuus (Sunflower), } \\
\text { S }\end{array}$ & Asteraceae & ++ & ++ & - \\
\hline Lactuca sativa (Lettuce), S & Asteraceae & - & - & - \\
\hline Pastinaca sativa (Parsnip), S & Apiaceae & - & - & - \\
\hline Tagetes patula (Fr. marigold), S & Asteraceae & - & - & - \\
\hline Zinnia violacea (Zinnia), S & Asteraceae & - & - & - \\
\hline
\end{tabular}

$\mathrm{x} \mathrm{S}=$ seedling, $\mathrm{F}=$ detached flower

$\mathrm{y}-,+,++,+++=0 \%, 0$ to $30 \%, 30$ to $60 \%,>60 \%$ disease incidence, respectively.

The I. perplexans isolates from China aster and sunflower were pathogenic to the reciprocal hosts and pathogenic to chrysanthemum and gerbera, causing moderate to high incidences of flower or seedling blight in these hosts, but were not pathogenic to burdock (Table 1). The burdock isolate caused a high incidence of seedling blight in that host, caused flower blight in chrysanthemum and gerbera at low and high incidences, respectively, but did not produce petal blight in China aster or seedling blight in sunflower. Severe petal blight symptoms in gerbera caused by I. perplexans are illustrated in Fig. 4. 


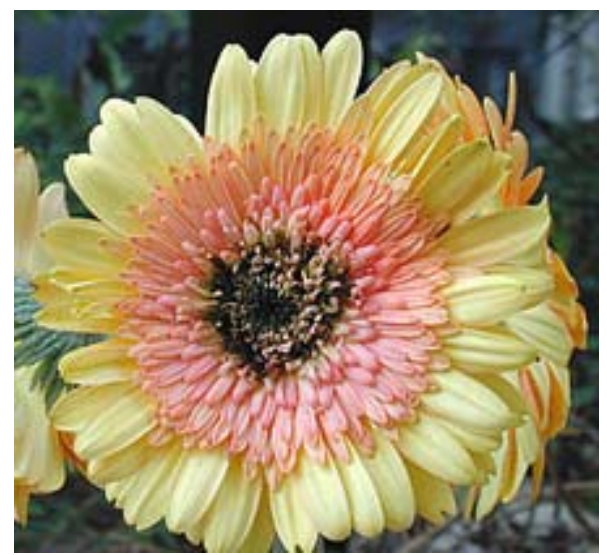

Fig. 4. Gerbera with symptoms of Itersonilia blight.

\section{Survey and Pathogenicity of Itersonilia perplexans from Weed Species}

A survey was conducted during February and March 2000, of weeds adjacent to the cut-flower production facility in Southwest Florida with a history of severe outbreaks of Itersonilia petal blight. Petals from eight wild plant species exhibiting flower lesions or blighting were surface disinfested in $0.5 \% \mathrm{NaOCl}$ for $20 \mathrm{~s}$, rinsed twice in sterile deionized water for $2 \mathrm{~min}$, suspended over $1 / 4^{-}$ strength APDA, and incubated at $15^{\circ} \mathrm{C}$ for 6 to 8 days. All weeds surveyed were negative for I. perplexans, except Emilia fosbergii (red tassel-flower) which was found to be infected at an incidence of $20 \%$ (Table 2) (Fig. 5).

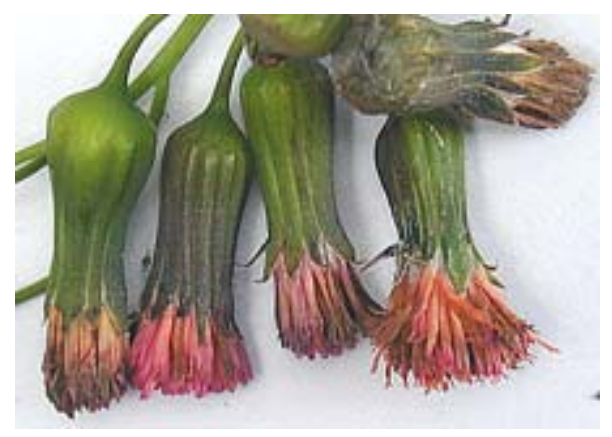

Fig. 5. Emilia fosbergii with blight symptoms and signs of I tersonilia perplexans.

Table 2. Survey for Itersonilia perplexans in weeds at a cut-flower production site in Southwest Florida, February and March 2000.

\begin{tabular}{|l|c|c|}
\hline \hline Weed $^{\mathrm{x}}$ & $\begin{array}{c}\text { Number of } \\
\text { plants sampled }\end{array}$ & $\begin{array}{c}\text { I. perplexans } \\
\text { recovery (\%) }\end{array}$ \\
\hline Bidens bipinnata & 18 & 0 \\
\hline Eclipta prostrate & 7 & 0 \\
\hline Emilia fosbergii & 10 & 20 \\
\hline Gaillardia sp. & 4 & 0 \\
\hline Lepidium virginicum & 10 & 0 \\
\hline Ludwigia sp. & 6 & 0 \\
\hline Rudbeckia sp. & 10 & 0 \\
\hline Sonchus sp. & 43 & 0 \\
\hline
\end{tabular}

\footnotetext{
${ }^{\mathrm{x}}$ Flowers exhibiting petal spots, blight, or necrosis were sampled.
} 
The pathogenicity of two I. perplexans isolates (E-1, E-2) recovered from the weed E. fosbergii was tested using detached flowers of the weed and China aster. Single isolates of the fungus from China aster (98-592) and sunflower (99-1051) were also used to inoculate flowers of E. fosbergii and China aster. Flower peduncles were placed in flasks containing sterile, deionized water. Flowers of E. fosbergii and China aster were inoculated with 0.25 and $1.0 \mathrm{ml}$, respectively, of a suspension containing $1 \times 10^{4} / \mathrm{ml}$ suspension of I. perplexans. Flowers were enclosed in plastic bags and held at $15^{\circ} \mathrm{C}$ for 6 to 8 days. After incubation, flowers were examined for Itersonilia petal blight, and the fungus was reisolated as previously described. The pathogenicity of I. perplexans isolates from $\mathrm{E}$. fosbergii were tested on China aster and E. fosbergii two and three times, respectively. The pathogenicity of I. perplexans isolates from China aster and sunflower were tested on China aster and E. fosbergii one and two times, respectively.

Back transmission of isolates E-1 and E-2 to E. fosbergii resulted in an 88.7\% and $75.1 \%$ incidence of petal blight, respectively. The aster and sunflower isolates of I. perplexans also infected E. fosbergii and produced petal blight incidences of $66.0 \%$ and $68.8 \%$, respectively. All four isolates produced severe petal blight in China aster at an incidence of $100 \%$.

\section{Evaluation of Fungicides for Control of Petal Blight}

Fully-open flowers of China aster 'Matsumoto Blue' were cut to leave 2.5 to $5.0 \mathrm{~mm}$ stem segments. The stems were then immersed in sterile deionized water and placed within a moist chamber (bell jar). Enclosed flowers were maintained in a controlled environment chamber at $15^{\circ} \mathrm{C}$ with a 12 -h photoperiod. Each treatment (fungicide) or control (water) was replicated three times using a randomized complete-block design; five flowers in each moist chamber served as a treatment replication. Fungicides evaluated included two new reduced-risk materials, Armicarb 100 (potassium bicarbonate; $4.2 \mathrm{lb} / 100$ gal) and Heritage (azoxystrobin; $2.0 \mathrm{oz} / 100$ gal), which were compared with two standard compounds, Systhane WSP (myclobutanil; 4 oz/ 100 gal) and Banner Maxx (propiconazole; $5 \mathrm{fl} \mathrm{oz/} 100 \mathrm{gal}$ ). Fungicides were applied to run-off using a hand-operated hydraulic sprayer $24 \mathrm{~h}$ before inoculation with a 1-ml suspension of $1 \times 10^{4}$ ballistospores/ $\mathrm{ml}$ of I. perplexans isolate 98-592 (China aster). Disease severity (flower blight percentage) was estimated 5, 7, and 9 days after inoculation, and the area under the disease (severity) progress curve (AUDPC) was calculated. Treatment means were separated using Fisher's Protected LSD following appropriate data transformation. The experiment was conducted twice.

Systhane WSP, Amicarb 100, and Banner Maxx significantly reduced Itersonilia petal blight severity in both experiments compared to the non-treated control (Table 3). Heritage reduced disease severity only in experiment two. All fungicides significantly reduced the progress of petal blight (AUDPC), with Systhane WSP, Armicarb 100, and Banner Maxx as the most effective. 
Table 3. Effect of fungicides on Itersonilia petal blight in China aster 'Matsumoto Dark Blue.'

\begin{tabular}{|l|c|c|c|c|}
\hline \multirow{2}{*}{ Treatment } & \multicolumn{1}{|c|}{ Final disease severity $(\%)^{\mathrm{x}}$} & \multicolumn{2}{|c|}{ AUDPC } \\
\cline { 2 - 5 } & $\begin{array}{c}\text { Experiment } \\
\mathbf{1}\end{array}$ & $\begin{array}{c}\text { Experiment } \\
\mathbf{2}\end{array}$ & $\begin{array}{c}\text { Experiment } \\
\mathbf{1}\end{array}$ & $\begin{array}{c}\text { Experiment } \\
\mathbf{2}\end{array}$ \\
\hline Control & $48.6 \mathrm{a}^{\mathrm{y}}$ & $48.3 \mathrm{a}$ & $173.9 \mathrm{a}$ & $165.0 \mathrm{a}$ \\
\hline Heritage & $33.3 \mathrm{a}$ & $20.3 \mathrm{~b}$ & $75.8 \mathrm{~b}$ & $65.1 \mathrm{~b}$ \\
\hline Systhane WSP & $4.6 \mathrm{~b}$ & $5.8 \mathrm{c}$ & $18.6 \mathrm{~b}$ & $20.8 \mathrm{c}$ \\
\hline Armicarb 100 & $2.6 \mathrm{~b}$ & $2.0 \mathrm{~d}$ & $13.0 \mathrm{~b}$ & $9.2 \mathrm{c}$ \\
\hline Banner Maxx & $2.7 \mathrm{~b}$ & $1.2 \mathrm{~d}$ & $12.0 \mathrm{~b}$ & $5.2 \mathrm{c}$ \\
\hline
\end{tabular}

$\mathrm{x}$ Arc sine square root transformation of percentage data was performed prior to data analysis; non-transformed means are presented.

$y$ Means within columns followed by different letters are significantly different $(P \leq 0.001)$ by Fisher's Protected LSD.

\section{Management I mplications for I tersonilia Petal Blight in Cut- Flower Production}

Isolates of Itersonilia perplexans from China aster and sunflower did not infect seedlings of parsnip, dill, or other plant species but did cause disease in flowers of chrysanthemums and gerbera. This finding suggests that isolates from China aster are similar to chrysanthemum isolates in that they infect floral parts of plants in the Asteraceae but do not infect plants in the Apiaceae (dill, parsnip, etc.) (6). The isolate from sunflower was originally reported for the first time to cause post-harvest petal blight in sunflowers (22). Because these isolates can infect other hosts which may be produced in the same facility and because the fungus can survive on senescent tissue and plant debris even at low temperatures (11), the use of effective sanitation methods is critical in controlling outbreaks of petal blight.

Itersonilia perplexans was found in only one weed, E. fosbergii, when weeds near the production facility were surveyed. However, two isolates from $\mathrm{E}$. fosbergii were capable of causing severe disease when inoculated onto China aster. Outbreaks of Itersonilia petal blight have recently occurred in chrysanthemum cut-flower production facilities in Hawaii (J ane Trollinger, personal communication), and it is interesting to note that E. fosbergii also occurs naturally in Hawaii (1). In a previous study, McGovern and Seijo (16) found that I. perplexans could experimentally infect Bidens bipinnata L., although the fungus was not found occurring naturally in this plant species around the production facility. In both studies, the surveys for infected or colonized weeds were done after the outbreak of disease. Weed control in and around production facilities may help limit initial inoculum during cut-flower production, particularly when environmental conditions are favorable for outbreaks of petal blight (cool, wet weather).

Myclobutanil Systhane WSP), potassium bicarbonate (Armicarb 100), and propiconazole (Banner Maxx) were highly effective in reducing disease severity of petal blight in China aster, while Heritage reduced disease moderately in these trials. Potassium bicarbonate (Armicarb 100) is a reduced risk fungicide which has a zero-day pre-harvest interval on many crops. These findings provide some effective disease management measures for outbreaks of Itersonilia petal blight.

\section{Acknowledgments}

This research was supported by the Florida Agricultural Experiment Station. Support for this research was also provided by the Hokkaido Ornamental Plants and Vegetables Research Center. The use of trade names in this publication is solely for the purpose of providing specific information. The authors and the University of Florida-IFAS do not guarantee or warranty the products named, and references to them in this publication do not signify approval to the exclusion of other products of suitable composition. 
Literature Cited

1. Anonymous. 2006. Plant profile: Emilia fosbergii. Online. USDA National Resource Conservation Service Plants Database. Washington, DC.

2. Bedlan, G. 1988. First evidence of Itersonilia perlexans Derx on dill in Austria. Pflanzenshutzberichte 49:43-44. (In German).

3. Boekhout, T. 1991. Systematics of Itersonilia: A comparative phenetic study. Mycol. Res. 95:135-146.

4. Boekhout, T., Poot, G., and Hackman, P. 1991. Genomic characteristics of strains of Itersonilia: Taxonomic consequences and life cycle. Can. J . Microbiol. 37:188-194.

5. Brown, A., Nourish, W. H., and Fletcher, J. T. 1964. The effect of spacing and time of sowing on the incidence of parsnip canker. J . Hort. Sci. 39:103-110.

6. Channon, A. G. 1963. Studies on parsnip canker. I. The causes of the disease. Ann. Appl. Biol. 51:1-15.

7. Cragg, I. A. 1966. Itersonilia perplexans on globe artichoke. Plant Pathol. 15:47.

8. Derx, H. G. 1948. Itersonilia, noveau genre de sporolomycetes a mycelium boucle. Bull. Bot. Gard. Buitenzorg Ser. III. 17:465-472.

9. Dosdall, L. T. 1956. Petal blight of chrysanthemums incited by Itersonilia perplexans. Phytopathology 46:231-232.

10. Farr, D. F., Rossman, A. Y., Palm, M. E., and McCray, E. B. 2005. Online. Fungal Databases, Systematic Botany \& Mycology Laboratory, ARS, USDA.

11. Gandy, D. G. 1966. Itersonilia perplexans on chrysanthemums: Alternate hosts and ways of overwintering. Trans. Brit. Mycol. Soc. 49:499-507.

12. Horita, H., McGovern, R. J., Komatsu, T., and Yasuoka, S. 2005. Effects of inoculum density, leaf age, moisture, temperature, and wetness duration on black streak of edible burdock. J. Gen. Plant Pathol. 71:247-252.

13. Horita, H., and Yasuoka, S. 1998. Itersonilia perplexans, the causal agent of black streak on edible burdock. Ann. Phytopathol. Soc. J apan. 64:431 (Abstr. In J apanese).

14. Horst, R. K. 1997. Compendium of Chrysanthemum Diseases. The American Phytopathological Society, St. Paul, MN.

15. Koike, S. T., and Tjosvold, S. A. 2001. A blight disease of dill in California caused by Itersonilia perplexans. Plant Dis. 85:802

16. McGovern, R. J., and Seijo, T. E. 1999. Petal blight of Callistephus chinensis caused by Itersonilia perplexans. Plant Dis. 83:397.

17. McRitchie, J. J., Kimbrough, J. W., and Englehard, A. W. 1973. Itersonilia petal blight of chrysanthemum in Florida. Plant Dis. Reptr. 57:181-182.

18. Nishihara, N. 1958. Petal blight of chrysanthemum. Plant Prot. 12:441-445. (In Japanese).

19. Nyland, G. 1949. Studies on some unusual Heterobasidiomycetes from Washington state. Mycologia 41:686-701.

20. Sackston, W. E. 1953. A species of Itersonilia pathogenic on sunflowers. Proc. Can. Phytopathol. Soc. 22.

21. Sackston, W. E. 1958. Itersonilia perplexans on sunflowers in Uruguay. Phytopathology 48:108-109.

22. Seijo, T. E., McGovern, R. J., and Marenco de Blandino, A. 2000. Petal blight of sunflower caused by Itersonilia perplexans. Plant Dis. 84:1153.

23. Singh, G., and Milne, K. S. 1974. Field evaluation of fungicides for the control of chrysanthemum petal blight. N. Z. J. Exp. Agric. 2:185-188.

24. Sowell, G., and Korf, R. P. 1960. An emendation of the genus Itersonilia based on studies of morphology and pathogenicity. Mycologia 52:934-945.

25. Walker, J . 1957. Diseases of parsnips. Agric. Gazette of New South Wales 68:404406.

26. Wilkinson, R. E. 1952. Parsnip canker is caused by Itersonilia sp. Phytopathology 42:23. 